Hanna Sokolova,

PhD (Candidate of Psychological Sciences), senior lecturer, South Ukrainian National Pedagogical University named after K. D. Ushynsky, 4, Fontanska Doroha Str., Odesa, Ukraine

\title{
PSYCHOLOGICAL CHARACTERISTICS OF DEFENSIVENESS \\ OF PARENTS RAISING CHILDREN WITH DOWN'S SYNDROME
}

One of the important signs of psychological reality in families raising children with Down's syndrome is the use of various psychological defense mechanisms by parents, which greatly simplifies the experiencing of difficult life situations. The study is aimed at investigating the peculiarities of parents' defensiveness as a significant component of their psychological reality. The survey involved 120 people (80 mothers and 40 fathers) raising children with Down's syndrome. The following research tools were used in the experiment: Life Style Index by P. Plutchik and G. Kellerman aimed to examine the defensiveness of the surveyed, and the test "Interaction between parent and their child" by I. Markovska was applied to assess the interaction between the surveyed and their children. Among eight defensiveness mechanisms, the severity of the four following ones significantly distinguishes mothers and fathers: repression, regression, intellectualization, and reaction formation. The greatest differences have been found in the use of regression: mothers often use this mechanism, whereas fathers are more likely to rationalize and schematize anxious feelings and thoughts using intellectualization. Mothers also tend to transform negative feelings into opposite ones (reaction formation). If socio-normative level of defensiveness intensiveness is conditioned by socio-cultural peculiarities of the society, the research results are considered to be alarming, because it means that the social conditions of the Ukrainian society do not contribute to the formation of harmonious relations between parents and their abnormal children. Along with this, the defensiveness of not only parents but also other family members should be taken into account and investigated.

Keywords: personality, down syndrome, psychological reality, psychological defense mechanism, style of parentchild interaction.

Подано до редакиії 06.02.2017

Рецензент: д. психол. н., проф. 3. О. Кіреєва

UDC: $159.98-051: 159.942 .5$

DOI: https://doi.org/10.24195/2414-4665-2017-3-5

\author{
Maryna Mischenko, \\ PhD (Candidate of Psychological Sciences), senior lecturer, \\ Department of Psychology, \\ Nataliia Shelenkova, \\ PhD (Candidate of Psychological Sciences), associate professor, \\ Department of Psychology, \\ Pavlo Tychyna Uman State Pedagogical University, \\ 2, Sadova Str., Uman, Ukraine
}

\section{FUTURE PSYCHOLOGISTS' BURNOUT SYNDROME: RESULTS OF AN EMPIRICAL STUDY}

The issue of psychologists' burnout is one of the most important in the aspect of improvement of future psychologists' professional training. Mastering professional skills leads to a gradual change in the structure of future psychologists' personality: there is consolidation and intensive development of personal qualities that promote successful activity, on the one hand, and changes, inhibition and even destruction of balancing structures that are not involved in the process of professional development, on the other. The article deals with the relationship among burnout syndrome, psychological defense mechanisms and individual psychological characteristics. To achieve the goal of the study psychodiagnostic methods allowing to investigate future psychologists' burnout syndrome have been used. Based on these data using correlation analysis the relationship among burnout syndrome, psychological defense mechanisms and individual psychological characteristics has been revealed.

Keywords: psychologist, burnout, professional activity, psychological defense mechanisms, individual psychological characteristics.

\section{Introduction}

The system of higher education puts forward new requirements for future psychologists' training and, therefore, contradictions in the sphere of professional selfrealization are appearing. It is important for future profes- sionals not only to gain knowledge and skills, but also learn to overcome difficulties and solve problems that arise from the impact of their professional activity on the individual. In particular, when working in uncertain crisis situations, which are the basis of educational and profes- 
sional activities aimed at providing volunteer psychological support for bereaved families, participants of antiterrorist operations, immigrants, war-affected people and people in difficult life circumstances. It is stated in numerous regulations, such as: paragraph 2.2. of the Ministry of Education and Science of Ukraine Board's decision "On the state and problems of psychological assistance to subjects of education under conditions of anti-terrorist operations in the East of the country" (Record No. 3/3-3 dated 26.03.2015); the letter from Ministry of Education and Science of Ukraine "On the training program and training course to increase practical psychologists and social workers' qualification level on the issue "Crisis counseling skills and development of children's psychosocial stress resistance" (dated 09.06.2015 № 1/9-284) and others.

The most developed aspects of burnout syndrome are the following: investigations of its essence and structure (S. Maksymenko, L. Karamushka, J. Freidenberg, H. Maslach, M. Barish, S. Kahili, V. Shaufeli, H. Syksma, V. Dudiak); development of psychodiagnostic instruments (V. Boiko, N. Vodopyanova, O. Rukavishnikov) and means of prevention and correction (K. Lavrova, Ye. Ilyin, M. Avramenko, M. Borysova, A. Vasylenko, M. Vorontsova, N. Hrysenko). There are important studies on the research topic, which highlight the problems of practical psychologists' professional development (O. Kokun, N. Shevchenko, N. Shelenkova, L. Pomytkina, T. Tytarenko); a specific character of their professional activity (N. Povyakel, V. Panok); student psychologists' emotional stability (K. Pylypenko).

Despite a great number of publications devoted to burnout syndrome, it has not been established what exactly influences the development of this phenomenon in future psychologists. An important result when introducing students into the practical sphere is their psychological readiness for future professional activities. However, researchers have concluded that there is a tendency towards the reduction of its level within their professional career (N. Shelenkova); the fourth year study crisis (O. Chuiko); experience of some "inner semantic conflict" (N. Shevchenko) and so on. Owing to these and other conditions, burnout syndrome, which occurs in situations of intensive professional interaction, appears. Nevertheless, peculiarities of future psychologists' professional activity in crisis situations and their influence on this phenomenon formation have not been highlighted in domestic scientific literature.

The aim of the article is to discover the relationship among burnout syndrome, psychological defense mechanisms and individual psychological characteristics of personality.

To achieve the goal, the following research methods were used: theoretical (analysis, synthesis, generalization and systematization of theoretical foundations on this subject); statistical (correlation analysis); psychodiagnostic methods: "Diagnosis of burnout level" (V. Boiko), "Evaluation of psychic burnout" (O. Rukavishnikov), "Burnout syndrome in professions of the system "Person-to-person", "Combined personality questionnaire" (H. Leievyk), "Lifestyle index questionnaire" (Plutchyk-Kelerman-Konte).

\section{Discussion}

Burnout syndrome is the result of integration of physical, emotional and cognitive exhaustion or fatigue, in which the main factor is emotional exhaustion [3, p. 18].

V. Dudiak has found out that specialists, who have to contact with other people intensively due to the nature of their professional activities, are more inclined to burnout (psychologists, teachers, social workers, lawyers, doctors and others). During their work the representatives of these professions feel a strong nervous and mental load, after which there is emotional fatigue; behaviour, feelings, thinking, health, attitudes to work, to others and to their own lives are changed [1, p. 1].

In the professions, based on the communicative relations, long-term, diverse and difficult cognitiveemotional situations of communication with other people require interrelations of a completely different quality (trust, professionalism, emotional stability, etc.) and communicative competence, as it greatly influences the results of this cooperation and prospects of future business and interpersonall contacts. Therefore, a frequent lack of positive result or motivational reinforcement (positive feedback) is determined by the specificity of their professional activity [2, p. 557].

A future psychologist, involved in the long-term intensive communication with other people, is characterized by burnout syndrome. This is also related to the fact that specialists in their activities, in addition to their professional knowledge and skills, use their own personality heavily, and they are a sort of "emotional donors".

With the formation of professional knowledge, students understand the details of their future profession better, they form a certain attitude to future professional activity. During their student years young people have to withstand very high loads - physical, mental, moral, volitional. Not all students can estimate their own resources and organize their work efficiently.

Future psychologists improve their practical skills during the internships (fact-finding, educational, professional, psychocorrectional and state). At this stage, future professionals are influenced by professional stress, leading to emergence and development of burnout syndrome.

In Ukraine the problem of future psychologists' professional training has become the most important and acute recently, as there are subject areas where the qualified psychologists and professionals' assistance is necessary. The psychological assistance to victims of the situation in the country becomes particularly relevant under conditions of counteracting the aggression and military actions in the East of Ukraine. Future psychologists must be ready to work with the military with post-traumatic stress syndrome, promote their further psychological rehabilitation to the conditions of peaceful life, help the civilian population and work in extreme situations. The Round Table Recommendations 
"Ukrainian children in the current crisis conditions. Peculiarities of national and patriotic education" (Kyiv, 17.09.2015) include the following issues: improvement of quality of psychologists' training, implementation of educational training courses aimed at considering features of work with children suffering psychological injuries due to the military operations; introduction of retraining and advanced training programs on socio-psychological rehabilitation of children of crisis categories for practical psychologists of education institutions. Consequently, one of the aspects of future psychologists' internships is to attract students to the centre of psychological support for bereaved families, ATO participants' families, internally displaced people. The improvement of future specialists' practical training is carried out in uncertain and crisis situations.

The concept of "crisis" (from the Greek crisis - a decision, turning point) means that it is generated by a problem that confronts the individual and which can't be avoided and solved in a short period of time and in a regular way. F. Vasilyuk suggests that a crisis situation is a situation in which the subject is faced with the impossibility of the realization of their life internal needs (motives, aspirations, values, etc.).

From our point of view, a crisis situation is a situation in which a future specialist experiences a great deal of mental stress caused by force tension in order to overcome absolutely new problems, inability to help and internal inconsistency between readiness for the implementation of various activities (expectations) and the ability to apply this knowledge in practice (reality).

The period of professional training, participation in professional activity is one of the important stages of identity formation and it is characterized not only by an active mastering of professional knowledge and skills, but also by substantial changes in the field of consciousness.

While studying in higher educational institutions, future psychologists' personal qualities, which will influence the professional activity effectiveness and prevent emergence and manifestation of burnout syndrome, must be formed.

The level of students' psycho-physical culture during their studies at university is being reduced due to a rapid growth of informational and emotional loads that cause a significant deterioration in mental health, increased anxiety, estrangement, which prevent them from overcoming a stressful situation.

Feelings of self-worthlessness, indifference to professional activities, loss of important life values lead to reduction in intrapersonal resources, development of psychosomatic disorders and as a result - development of burnout syndrome.

The necessity of prevention of future practical psychologists' burnout is determined by the fact that psychologists' burnout stability depends on their professional competence development.

The experiment took place on the basis of Pavlo Tychyna Uman State Pedagogical University, Lesya Ukrainka Eastern European National University,
Kirovohrad Volodymyr Vynnychenko State Pedagogical University, Mykolayiv National University named after V. O. Sukhomlinsky (2013-2014). Full time students of $4^{\text {th }}-5^{\text {th }}$ courses majoring in psychology (specialty "Practical psychology") were involved in the research. The total number of students is 180 people.

The analysis of correlation links of methods "Diagnosis of burnout level" (V. Boiko), "Evaluation of psychic burnout" (O. Rukavishnikov), "Lifestyle index questionnaire" (Plutchyk-Kelerman-Konte) has shown that all burnout phases are characterized by certain psychological defense mechanisms with a different dominance degree of the latter. Another feature is development of psychic burnout (taking into account psychologists' activities in the system "Person-to-Person"), namely, "psychoemotional exhaustion" and "personal estrangement" with which there is a positive correlation.

The inversely proportional relationship is observed with the component of psychic burnout - "professional motivation", which indicates a decrease in professional motivation with an increase in burnout. An interesting feature of burnout development according to the phases of V. Boyko's method is growth of a negative correlation on psychological defense mechanism "Rationalization" (tension phase $r=-, 362$; resistance phase $r=-, 387$, exhaustion phase $r=-405$ ), i.e. rational self-explanation of certain facts, events, etc. is reduced. The same tendency is also relevant for two stages (Emotional exhaustion $\mathrm{r}=-, 389$ and Depersonalization $\mathrm{r}=-, 379)$, but at the stage of Reduction of personal achievements the correlation relationship of rationalization $(r=0,303)$ becomes positive. This may indicate that at the stage of Reduction of personal achievements rationalization mechanism, subjective explanations of actions or inactivity are activated. An identical tendency is typical for "professional motivation" ( $\mathrm{r}=0,290)$.

Based on the analysis of correlation links between burnout phases and individual characteristics we have revealed the following behavior features common to all phases which occur as a result of burnout syndrome of the: with an increase in burnout severity there is a decrease in openness (unsociability is increased - the strongest relationship $-0,753 ;-0,802 ;-0,791$ at the significance level $\mathrm{p} \leq 0,0001$ ), limitation in contacts, conformity and rudeness in communication are increased.

It should be mentioned that such a characteristic of communicative sphere as trustfulness undergoes practically no changes with burnout development (except significant but irrelevant changes in the first phase of "tension"). This can be explained by psychologists' professional skills developed empathy, willingness to help, empathy.

Changes in emotional sphere are characterized by emotional depletion, increased tension and diffidence. As in the previous sphere, the factor of emotional sensitivity isn't changed and remains constant $(0,093 ; 0,095 ; 0,077)$.

Burnout affects emotional and volitional spheres by a considerable reduction in emotional reactions control and a gradual decrease in discipline (sense of responsibility). There are no significant correlations in 
intellectual sphere. It shows that the intellectual sphere features have no influence either on burnout genesis or motivational sphere in principle.

An element of the system of relations is "Job dissatisfaction", which increases with burnout. Naturally, peculiarities of psychological climate and attitude to the chief (not only personal sphere features) remain unchanged.

In the period of professional training in higher education institutions students should become familiar with their professional possibilities and consequences of activities in the field of psychological protection of the population, acquire skills of self-control, self-esteem, ability to manage their emotions and so on.

\section{Conclusions}

The results obtained clarify the role of students'psychological defense mechanisms and individual psychological characteristics in the formation of burnout

\section{REFERENCES}

1. Dudiak, V. (2007). Emotsiine vyhorannia [Burnout]. Kyiv: Hlavnyk [in Ukrainian].

2. Nikiforov, G. S. (2006). Psikhologiia zdorovya [Psychology of health]. Saint Petersburg: Piter [in Russian].

\section{ЛІТЕРАТУРА}

1. Дудяк В. Емоційне вигорання / В. Дудяк. К. : Главник, 2007. - 126 с.

2. Никифоров Г. С. Психология здоровья / Г. С. Никифоров. - СПб. : Питер, 2006. - 607 с. syndrome. To sum up, we claim that "Psychodynamic sphere" in the totality of its components, reacts to burnout development the most actively. Introversion, anxiety and rigidity are growing. People become anxious, unable to rebuild and adapt to changing environmental conditions quickly and switch their attention from one business to another easily.

The scholars believe that burnout can be developed into professional burnout, i.e. global destructive phenomenon that extends to all professional activities of the person, which is unacceptable for psychologist's work. Therefore, the preservation of future psychologists' psychological health is a task of current importance at the present stage of society development.

Prospects for further research are the necessity to find effective forms, methods and means preventing future psychologists' burnout syndrome at the stage of introduction into professional activities.

3. Poliakova, O. B. (2008). Psikhogigiyena i profilaktika professionalnykh deformatsiy lichnosti [Psychohygiene and prevention of personal professional deformations]. Moscow: MPSI.

3. Полякова О. Б. Психогигиена и профилактика профессиональных деформаций личности / О. Б. Полякова. - М. : МПСИ, 2008. - 304 с.

\section{Марина Сергївна Міщенко, кандидат психологічних наук, старший викладач кафедри психології, Наталія Леонідівна Шеленкова, кандидат психологічних наук, доиент кафедри психології, Уманський державний педагогічний університет імені Павла Тичини, вул. Садова, 2, м. Умань, Украӥна}

\section{СИНДРОМ ЕМОЦІЙНОГО ВИГОРАННЯ У МАЙБУТНІХ ПСИХОЛОГІВ: РЕЗУЛЬТАТИ ЕМПІРИЧНОГО ДОСЛІДЖЕННЯ}

Проблема емоційного вигорання є однією з центральних в аспекті вдосконалення фахової підготовки майбутніх психологів. Оволодіння майбутніми психологами професійними навичками зумовлює поступову зміну структури їхньої особистості: з одного боку, відбувається посилення й інтенсивний розвиток якостей, що сприяють успішній діяльності, а з іншого - зміна, придушення і навіть руйнування балансуючих структур, що не беруть участь у процесі професійного становлення. У статті розглядається взаємозв'язок синдрому емоційного вигорання 3 механізмами психологічного захисту та індивідуально-психологічними особливостями. Для вирішення поставленої мети у дослідженні було обрано психодіагностичні методики, що дозволяють всебічно дослідити синдром емоційного вигорання у майбутніх психологів. На підставі отриманих даних за допомогою кореляційного аналізу виявлено взаємозв'язок синдрому емоційного вигорання з механізмами психологічного захисту та індивідуально-психологічними особливостями. У результаті аналізу кореляційних зв'язків у досліджуваних стає зрозумілою роль механізмів психологічного захисту та індивідуально-психологічних особливостей студентів у формуванні синдрому емоційного вигорання. «Психодинамічна сфера» у сукупності компонентів найактивніше реагує на становлення емоційного вигорання. Зростає інтровертованість, тривожність та ригідність. Людина стає стурбованою, важче перебудовується i пристосовується до змінених умов середовища, важко переключається з однієї справи на іншу. Емоційне вигорання може перерости навіть у професійне вигорання - глобальний деструктивний феномен, що поширюється на всю професійну діяльність особи, що є неприпустимим для роботи психолога. Тому збереження психологічного здоров'я майбутніх психологів $є$ надзвичайно актуальним завданням на сучасному етапі розвитку суспільства. Перспективою 
подальших розвідок є пошук ефективних форм, методів і засобів попередження синдрому емоційного вигорання майбутніх психологів на етапі підготовки до професійної діяльності.

Ключові слова: психолог, емоційне вигорання, професійна діяльність, механізми психологічного захисту, індивідуально-психологічні особливості.

Submitted on February, 6, 2017

Reviewed by Doctor of Psychology, prof. O. Safin

UDC: 159.922 .762

DOI: https://doi.org/10.24195/2414-4665-2017-3-6

Nataliia Sieromakha,

PhD (Candidate of Psychological Sciences), associate professor, Department of Defectology and Psychological Correction,

Luhansk Taras Shevchenko National University,

1, Gogolia Square, Starobilsk, Ukraine

\section{STUDYING THE FEATURES OF MENTALLY RETARDED ADOLESCENTS' NONVERBAL BEHAVIOUR}

The paper is focused on the psychological essence of the concept "nonverbal behaviour"; its components have been specified, namely: understanding other people's nonverbal behaviour, the ability to correlate nonverbal characteristics corresponding to a certain emotional state; the level of verbal communication development, social experience in the process of assessing other people's behaviour according to the standards determined by moral criteria. The programme and the main findings of experimental research of the peculiarities of nonverbal behaviour in mentally retarded adolescents are represented.

Keywords: nonverbal behaviour, behaviour interpretation, the level of awareness, mental retardation, adolescence.

\section{Introduction}

The study of various aspects of behaviour, including features of nonverbal behaviour of mentally retarded children and adolescents, will contribute to the improvement of their social adaptation, search for the ways of correcting social and perceptive processes and behaviour in actual situations of interaction. Mentally retarded adolescents experience difficulties in interpersonal communication. It is difficult for them to understand other people's feelings clearly; their abilities to understand basic emotional states basing on facial expressions are also poor. It is explained by insufficiently developed skills of understanding nonverbal behaviour and organisation of their own nonverbal communication, which are formed much more slowly in mentally retarded adolescents. Therefore, this problem requires psychopedagogical investigation.

In the research works by Ch. Darwin, F. Delsarte, D. Efron, A. Sheflen, P. Ekman, nonverbal behaviour is considered as a complex of various body movements. H. Kovalova, V. Labunska, L. Kononovich, H. Mikkin believe that in psychological literature much attention is paid to the structure and elements of nonverbal behaviour, while psychological content of interpreting various types of nonverbal behaviour are underinvestigated.

Review of the research works dedicated to mentally retarded adolescents' behaviours, ways and means of its correction demonstrates detailed investigation of these issues in the works on psychology and pedagogy for special needs by Ye. Albrecht, V. Bondar, O. Bazhukova, I. Bhazhnokova, Yu. Bystrova, L. Vygotsky, S. Horbenko, H. Zapriahaieva, V. Kovalova, K. Lebedynska, M. Matvieieva, Zh. Namazbaieva, V. Kuzmina, M. Pevzner, O. Romanenko, V. Synova, O. Sieverova, H. Sukhareva, O. Khokhlina and others. Some aspects of studying nonverbal behaviour of mentally retarded adolescents were considered in the works of M. Ahavelian, O. Ahavelian, Yu. Mendzherytska, Ye. Breus, N. Cherepkov, L. Korshykov. However, the impact of nonverbal information on perception, regulation and interpretation of mentally retarded adolescents' behaviour remains understudied in psychology for special needs.

The paper aims to study the features of nonverbal behaviour in mentally retarded adolescents.

\section{Discussion}

Nonverbal behaviour as well as behaviour in general is a combination of individual, personal forms of behaviour with the group, socio-cultural ones. L. Korshykova, V. Labunska, D. Matsumoto, N. Cherepkov think that nonverbal behaviour involves all kinds of behaviour demonstrated in the process of communication except for the pronounced words. These nonverbal aspects of behaviour include facial expressions, hand and leg gestures, postural pose, lean and orientation of the body, voice tone and other vocal characteristics (pitch, speech tempo, intonation and 